\title{
ANALISIS KEMAMPUAN MENULIS KARANGAN NARASI MENGGUNAKAN METODE SHOW NOT TELL PADA SISWA KELAS V MI NAHDLATUL MUJAHIDIN NW JEMPONG, AMPENAN
}

\author{
Baiq Desi Milandari', Roby Mandalika Waluyan* \\ 1*Fakultas IImu Keguruan dan IImu Pendidikan-Universitas Muhammadiyah Mataram, desibaiq_It@yahoo.co.id
}

INFO ARTIKEL

\section{Riwayat Artikel:}

Diterima: 05-06-2018

Disetujui: 12-07-2018

\section{Kata Kunci:}

Kemampuan

Metode show not tell

Karangan narasi

\section{A. LATAR BELAKANG}

Belajar bahasa dapat dikatakan sebagai proses belajar berkomunikasi. Pembelajaran bahasa, khususnya bahasa Indonesia dilakukan sebagai upaya meningkatkan kemampuan peserta didik dalam berkomunikasi. Kegiatan berkomunikasi tidak hanya terbatas pada komunikasi lisan, namun juga komunikasi tulisan. Pada saat ini, banyak bermunculan tuntutan untuk dapat menghasilkan tulisan, seperti diterbitkannya jurnal-jurnal hasil karya tulis. Adanya persoalan semacam itu, diharapkan penanaman kebiasaan menulis dimulai sejak dini pada peserta didik. Kebiasaan menulis dapat dilakukan dengan memberikan latihan-latihan yang intensif saat pelajaran bahasa Indonesia berlangsung.

Menulis merupakan suatau kegiatan yang sangat kompleks. Kompleks diartikan sebagai sesuatu yang tidak hanya mampu merangkai kata demi kata, kalimat demi kalimat, maupun paragraf demi paragraf agar menjadi tulisan yang padu, namun juga keluwesan berpikir menuangkan ide serta gagasan ketika proses menulis berlangsung. Kegiatan menulis memerlukan kombinasi di antara unsur-unsur tersebut sehingga
ABSTRAK

\begin{abstract}
Abstrak: Menulis merupakan salah satu kegiatan berbahasa yang begitu kompleks. Kegiatan dilakukan cara yang menyenangkan dan inovatif guna mengembangkan kreativitas siswa dalam menulis. Salah satunya yakni dengan cara menerapkan metode show not tell, khususnya menulis narasi. Berdasarkan paparan di atas, tujuan penelitian ini adalah untuk mendeskripsikan data obyektif tentang kemampuan menulis karangan menggunakan metode show not tell pada siswa kelas $\vee$ MI Nahdlatul Mujahidin Jempong, Ampenan. Adapun populasi dan sampelnya yakni siswa kelas $V$ MI Nahdlatul Mujahidin Jempong yang berjumlah 19 orang. Hasil penelitian ini adalah (1) kemampuan individual kategori tinggi sebanyak 17 orang siswadan kategori sedang berjumlah 3 orang siswa; (2) Persentase masing-masing kategori tinggi 85\%, kategori sedang 15\%, dan kategori rendah 0\%; (3) Indeks Prestasi Kelompok sebesar 85.5 sehingga termasuk dalam kategori IPK tinggi.
\end{abstract}

menjadikan kegiatan menulis sebagai suatu kegiatan yang sulit. Seperti yang diungkapkan Nurgiyantoro (2010: 422) bahwa menulis menghendaki penguasaan berbagai unsur kebahasaan dan unsur di luar bahasa itu sendiri yang akan menjadi isi karangan. Baik unsur bahasa maupun unsur isi pesan harus terjalin sedemikian rupa sehingga menghasilkan karangan yang runtut, padu, dan berisi.

Menulis berada pada tingkat intensitas penggunaan yang paling rendah. Dikatakan demikian, karena kegiatan menulis merupakan kegiatan yang paling jarang dilakukan. Jika diurutkan keempat keterampilan berbahasa yang paling sering dilakukan adalah dimulai dari kegiatan menyimak, berbicara, membaca, kemudian menulis. Menyimak sebagai kegiatan yang sangat sering dilakukan disebabkan oleh anak yang sejak lahir sudah melakukan aktivitas menyimak, disusul kemudian oleh kegiatan berbicara. Kegiatan membaca dan menulis dilakukan saat anak mulai memasuki bangku sekolah.

Salah satu keterampilan berbahasa yang paling tidak disukai murid dan gurunya adalah menulis atau mengarang. Pernyataan ini terbukti dari hasil survei yang dilakukan oleh Sugiran (2008: 54). Penyebab tidak 
disukainya kegiatan menulis oleh peserta didik di dalam mengikuti pelajaran bahasa Indonesia adalah adanya kesulitan yang dialami oleh peserta didik itu sendiri. Ini diungkapkan pula oleh Nurgiyantoro (2001: 296) yang mengatakan kemampuan menulis lebih sulit dikuasai bahkan oleh penutur asli bahasa yang bersangkutan sekalipun. Selain itu, faktor proses pembelajaran juga berpengaruh terhadap minat peserta didik dalam menghasilkan tulisan. Hal ini dapat disebabkan oleh seberapa besar indikasi dari proses pembelajaran yang dilakukan, seperti penerapan metode pembelajaran.

Tingkat kemampuan menulis dipengaruhi oleh beberapa faktor. Faktor-faktor tersebut berupa (1) intensitas peserta didik dalam kegiatan membaca, (2) tingkat imajinasi yang dimiliki peserta didik, (3) kemampuan menulis berdasarkan pengalaman, dan (4) metode dan media yang digunakan saat pembelajaran berlangsung.

Merunut pada apa yang dijelaskan sebelumnya, peneliti menemukan beberapa pengalaman di lapangan yang menyangkut tentang keterampilan menulis peserta didik. Banyak peserta didik, khususnya peserta didik pada tingkat SD masih sering mengalami kesulitan untuk memulai membuat sebuah tulisan. Ini disebabkan oleh keterbatasan mereka dalam hal pengalaman dan juga ide. Sehingga dengan demikian diperlukan adanya sebuah metode yang dirancang guru guna memudahkan daya kreativitas siswa untuk dapat menghasilkan sebuah tulisan.

Sebuah rancangan metode di dalam proses pembelajaran, khususnya pembelajaran bahasa Indonesia sangat penting. Hal ini berkaitan erat dengan langkah yang dilakukan guru dalam rangka mencapai tujuan dari pembelajaran. Tujuan pembelajaran akan tercapai apabila proses pembelajaran dilakukan dengan cara yang menyenangkan dan adanya langkah-langkah yang inovatif guna mengembangkan kreativitas siswa.

Salah satu metode yang dapat digunakan dalam kegiatan pembelajaran menulis, khususnya menulis narasi adalah metode show not tell. Metode ini pada dasarnya menekankan pada penggunaan daya kreativitas siswa dalam mengembangkan kata demi kata ataupun kalimat demi kalimat agar apa yang disampaikan kepada pembaca menjadi lebih hidup. Oleh karena itu, melalui penggunaan metode show not tell ini, peneliti ingin menganalisis kemampuan siswa kelas $\mathrm{V}$ MI Nahdlatul Mujahidin Jempong dalam menulis karangan narasi.

Berdasarkan paparan tersebut, rumusan masalah dalam penelitian ini adalah tentang bagaimanakah kemampuan menulis karangan menggunakan metode show not tell pada siswa kelas V MI Nahdlatul Mujahidin Jempong, Ampenan? Sejalan dengan itu, tujuan penelitian ini adalah untuk mengetahui kemampuan menulis karangan menggunakan metode show not tell pada siswa kelas V MI Nahdlatul Mujahidin Jempong, Ampenan.

\section{B. METODE PENELITIAN}

Penelitian ini merupakan penelitian kuantitatif deskriptif. Penelitian jenis ini digunakan untuk menggambarkan atau mendeskripsikan kemampuan menulis karangan narasi siswa kelas V MI Nahdlatul Mujahidin Jempong, Ampenan. Data kuantitatif yang akan diperoleh berupa hasil penilaian kemampuan menulis karangan narasi siswa menggunakan metode show not tell. Setelah itu, hasil tersebut kemudian dideskripsikan untuk mengetahui kemampuan menulis karangan narasi dengan menggunakan metode show not tell pada siswa kelas V MI Nadhlatul Mujahidin. Penelitian ini dilaksanakan di MI Nahdlatul Mujahidin NW Jempong, Ampenan. Pelaksanaannya berlangsung pada bulan Maret 2018.

Sampel adalah sebagian atau wakil dari populasi yang diteliti. Apabila subjeknya 100, maka lebih baik diambil semuanya sehingga penelitiannya merupakan penelitian populasi. Penelitian sampel baru boleh dilaksanakan apabila keadaan subjek di dalam populasi benar-benar homogen. Apabila subjek populasi tidak homogen, maka kesimpulan tidak boleh diberlakukan bagi seluruh populasi (Arikunto, 2010: 207). Berdasarkan pada pernyataan tersebut, maka peneliti memilih penelitian populasi karena jumlah siswa tidak lebih dari 100 orang siswa. Populasi yang yang diambil adalah seluruh siswa kelas V MI Nahdlatul Mujahidin NW Jempong yang berjumlah 19 orang siswa.

Teknik pengumpulan data dilakukan melalui observasi, penugasan, dan dokumentasi. Dalam penelitian ini observasi dilakukan dengan menggunakan teknik observasi struktur. Observasai terhadap siswa dilakukan untuk mengetahui situasi dan perkembangan kemampuan siswa dalam pembelajaran bahasa Indonesia, yang berfokus pada kemampuan menulis karangan narasi. penugasan dilakukan oleh Guru dan peneliti dengan menugaskan siswa V MI Nahdlatul Mujahidin Jempong untuk menyusun sebuah karangan narasi berdasarkan pengalaman pribadi dengan menggunakan metode show not tell. Analisis data dilakukan dengan menggunakan metode kuantitatif yakni dengan menentukan skor maksimal ideal, mean ideal dan standar deviasi.

\section{HASIL DAN PEMBAHASAN}

1. Persiapan Pembelajaran

Sebelum pelaksanaan proses pembeljaran berlangsung, guru bersama peneliti terlebih dahulu melakukan kolaborasi untuk menyusun serta mempersiapkan beberapa hal terkait dengan materi menulis karangan menggunakan metode show not tell pada siswa kelas V MI Nahdlatul Mujahidin NW 
Jempong. Hal ini penting agar tidak terjadi kesalahan persepsi antara guru dengan peneliti. Hal-hal yang harus disiapkan sebelum melaksanakan proses pemebalajaran di antaranya sebagai berikut. 1) Menyiapkan silabus bahasa Indonesia. 2) Menyusun RPP tentang menulis karangan narasi dengan menggunakan metode show not tell. 3) Menyiapkan materi pembelajaran tentang menulis karangan narasi. 4) Menyiapkan instrumen penilaian terkait dengan keterampilan menulis karangan narasi.

2. Tahap Pelaksanaan

Tahap pelaksanaan pembelajaran ini, guru menerapkan RPP yang sudah disusun dan ditelaah bersama peneliti. Pembelajaran ini berlangsung $2 \times$ 35 menit $(1 \times$ Pertemuan) yang telah disesuaikan dengan jadwal pelajaran bahasa Indonesia dan disusun berdasarkan silabus KTSP. Pelaksanaan pembelajaran tersebut menggunakan metode show not tell yang dapat membantu siswa untuk membuat karangan narasi. Metode show not tell memberikan kemudahan bagi siswa untuk melaksanakan tugas berdasarkan petunjuk guru. Selain itu, metode show not tell dapat melatih dan membiasakan siswa untuk bermain-main kata secara tepat.

a. Kegiatan Awal

Kegiatan awal merupakan kegiatan yang penting untuk diperhatikan oleh guru. Dalam kegiatan awal, guru harus mampu mengondisikan kelas agar siap menerima pelajaran. Beberapa hal yang dilaksanakan dalam kegiatan awal proses pembelajaran, yaitu: a) guru menyapa dan memeriksa kehadiran siswa, 2) guru dan siswa melakukan doa bersama dan mengkondisikan siswa agar siap menerima pelajaran, 3) siswa menyiapkan alat kelengkapan belajar dan tidak melakukan aktivitas lain saat guru berbicara di depan kelas, 4) guru menyiapkan media dan sumber belajar, 5) guru melakukan apersepsi tentang materi pembelajaran terdahulu, 6) guru menyampaikan tema dan tujuan pembelajaran yang akan diajarkan, yaitu tentang karangan narasi, 7) siswa mendengarkan penjelasan mengenai tema dan tujuan pembelajaran yang disampaikan guru.

b. Kegiatan Inti

Berhasil atau tidaknya suatu proses pembelajaran dapat dilihat dari pelaksanaan kegiatan inti. Kegiatan inti merupakan kegiatan pokok dalam sebuah proses pembelajaran. Dalam kegiatan inti tertuang strategi, metode, bahkan teknik dalam sebagai upaya mencapai tujuan pembelajaran. Dalam penelitian ini, proses pembelajaran menggunakan metode show not tell untuk memudahkan siswa menulis karangan narasi.

Adapun langkah-langkah dalam kegiatan inti, yaitu (1) Guru menyampaikan materi tentang karangan narasi; (2) Memberikan kesempatan kepada siswa untuk menanyakan hal-hal yang belum dipahami terkait materi narasi; (3) guru membagikan contoh karangan narasi untuk melihat unsur-unsur; (4) guru memberikan tugas kepada siswa untuk menulis karangan narasi dengan menggunakan metode show not tell; (5) Siswa dengan serius dan kosentrasi
Baiq Desi Milandari, ANALISIS KEMAMPUAN MENULIS...66

mengerjakan tugas menulis karangan narasi menggunakan metode show not tell yang diberikan guru.

c. Kegiatan Akhir

Setelah kegiatan inti terlaksana, guru bersama siswa melakukan refleksi terhadap proses pembelajaran yang telah berlangsung. Guru melakukan umpan balik dengan menanyakan pendapat siswa tentang pembelajaran hari ini, kemudian guru bersama siswa menyimpulkan hasil pembelajaran. Adapun penjabaran kegiatan dalam kegiatan akhir pembelajaran, yaitu (1) guru menanyakan tentang kesulitan selama proses belajar berlangsung; (2) guru dan siswa menyimpulkan materi pembelajaran; (3) guru menyampaikan materi pembeajaran pada pertemuan berikutnya; (4) guru memberikan tugas kepada siswa untuk kemudian dibahas pad pertemuan selanjutnya; dan (5) guru menutup pembelajaran dengan mengajak siswa berdoa.

3. Observasi dan Evaluasi

a. Observasi

Selama proses pembelajaran berlansung, dilakukan pengamatan terhadap aktivitas guru dan siswa. Berikut tabel observasi kegiatan guru.

TABEL 1.

LEMBAR OBSERVASI KEGIATAN GURU

\begin{tabular}{|c|c|c|c|c|}
\hline \multirow[b]{2}{*}{ No } & \multirow[b]{2}{*}{$\begin{array}{l}\text { Indikator/Deskr } \\
\text { iptor }\end{array}$} & \multicolumn{3}{|c|}{ Keterlaksanaan } \\
\hline & & $\begin{array}{c}\text { Maksi } \\
\text { mal }\end{array}$ & $\begin{array}{c}\text { Kurang } \\
\text { Maksima } \\
l\end{array}$ & $\begin{array}{c}\text { Tidak } \\
\text { Maksima } \\
\text { l }\end{array}$ \\
\hline
\end{tabular}

1. Kegiatan Awal

a. Menyapa

siswa,

memeriksa

kehadiran,

dan

mengkondisi

kan siswa

agar siap

menerima

pelajaran.

b. Melakukan

apersepsi

tentang

materi

pembelajara

n terdahulu.

c. Menyiapkan

media dan

sumber

belajar

d. Menyampaik an tujuan pembelajara $\mathrm{n}$.

2. Kegiatan Inti

a. Guru

menyampaik

an materi

tentang

karangan narasi.

b. Memberikan kesempatan

kepada siswa untuk

menanyakan

hal-hal yang

belum

dipahami

terkait 
materi

narasi.

c. Membagikan

contoh

karangan

narasi untuk

melihat

unsur-unsur.

d. Memberikan

tugas kepada

siswa untuk

menulis

karangan

narasi.

e. Memantau

siswa yang

sedang

mengerjakan

tugas

menulis

karangan

narasi.

f. Mengumpulk

an hasil kerja $\quad \checkmark$

siswa.

3. Kegiatan

Akhir

a. Melakukan

penyimpulan

terhadap

pembelajara

$\mathrm{n}$ yang telah

berlangsung.

b. Melakukan

refleksi.

c. Menutup

pembelajara

n.

Jika kita melihat tabel di atas, pelaksanaan dari indikator yang telah dibuat masih belum dijalankan secara maksimal oleh guru. Hal tersebut disebabkan oleh beberapa kendala, antara lain: (1) guru masih belum mampu menggunakan waktu secara maksimal, (2) karena kekurangan waktu, guru tidak melaksanakan penyimpulan dan refleksi pada akhir pertemuan, dan (3) guru belum maksimal dalam mengelola kelas sehingga masih ada siswa yang tidak fokus belajar.

Selain observasi terhadap aktivias guru, peneliti juga memantau aktivitas siswa selama proses pembelajaran menulis karangan narasi menggunakan metode show not tell. Adapun hasil pengamatan terhadap aktivitas siswa dapat dilihat pada tabel berikut.

TABEL 2.

LEMBAR OBSERVASI KEGIATAN SISWA

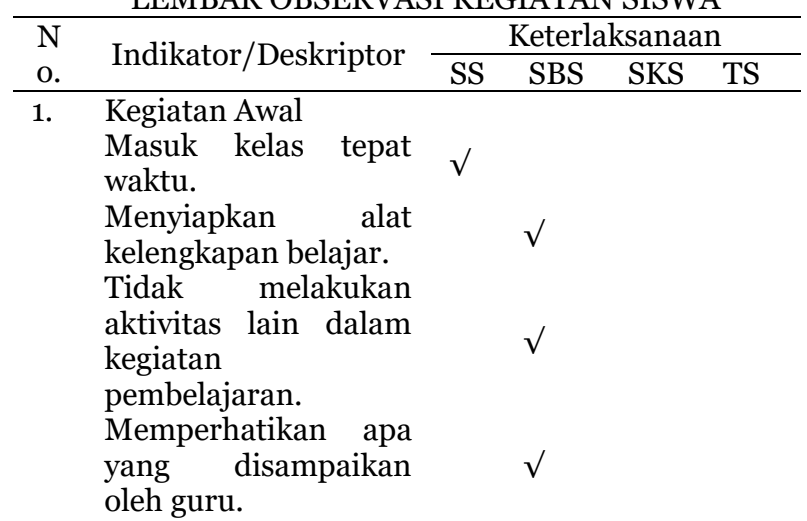

2. Kegiatan Inti

Mendengarkan

penjelasan guru

dengan seksama.

Menanyakan hal-hal

yang belum dipahami

(jika ada) terkait

dengan materi

karangan narasi.

Siswa menerima

contoh karangan

narasi.

Siswa mengerjakan

tugas yang diberikan

guru.

Siswa dengan serius

dan kosentrasi

mengerjakan tugas

yang diberikan.

Mengumpulkan hasil

menulis karangan

narasi yang telah $v$

diberikan kepada

guru.

3. Kegiatan Akhir

Bersama guru

melakukan

penyimpulan

terhadap

pembelajaran yang

telah berlangsung.

Menyampaikan kesan

dan pesan terkait

pembelajaran yang

telah dilaksanakan.

Mencatat

kesimpulan/rangkum

an materi yang

disimpulkan bersama.

Dengan memperhatikan tabel di atas, dapat kita lihat bahwa dalam melaksanakan pembelajaran tidak semua kegiatan dilaksanakan oleh semua siswa. Hal ini disebabkan oleh (1) pengelolaan waktu yang masih kurang baik; (2) beberapa siswa yang tidak fokus selama proses pembelajaran; serta (3) banyak siswa yang masih takut dan ragu bertanya dan mengeluarkan pendapatnya.

b. Evaluasi

Evaluasi dilakukan melalui hasil penugasan menulis karangan narasi menggunakan metode show not tell pada siswa kelas V MI Nahdlatul Mujahidin NW Jempong. Adapun hasil penilaian dapat dilihat melalui tabel di bawah ini.

TABEL 3.

HASIL PENILAIAN MENULIS KARANGAN NARASI MENGGUNAKAN METODE SHOW NOT TELL PADA SISWA KELAS V MI NAHDLATUL MUJAHIDIN JEMPONG

\begin{tabular}{|c|c|c|c|c|c|}
\hline \multirow{3}{*}{$\begin{array}{l}\mathbf{N} \\
\mathbf{o}\end{array}$} & \multirow{3}{*}{$\begin{array}{l}\text { Nama } \\
\text { Siswa }\end{array}$} & \multicolumn{4}{|c|}{ Kriteria Penilaian } \\
\hline & & & Organisa & & \\
\hline & & Isi & $\begin{array}{c}\text { si } \\
\text { Tulisan }\end{array}$ & Kosakata & $\underset{\mathbf{i}}{\mathbf{N i l a}}$ \\
\hline 1. & MRAR & 100 & 95 & 90 & 95 \\
\hline 2. & ML & 70 & 65 & 65 & 67 \\
\hline 3 . & MA & 87 & 90 & 85 & 87 \\
\hline 4 . & RAU & 57 & 40 & 45 & 47 \\
\hline 5. & HLM & 57 & 43 & 50 & 50 \\
\hline 6. & PMA & 83 & 85 & 90 & 86 \\
\hline 7 . & MJ & 100 & 100 & 95 & 98 \\
\hline 8. & HYM & 93 & 90 & 90 & 91 \\
\hline 9. & SDS & 83 & 75 & 85 & 81 \\
\hline
\end{tabular}




\begin{tabular}{llrccc} 
10. & NH & 93 & 95 & 95 & 94 \\
11. & ATF & 93 & 90 & 90 & 91 \\
12. & ARHD & 87 & 90 & 90 & 89 \\
13. & EAR & 97 & 95 & 85 & 92 \\
14. & AR & 97 & 95 & 95 & 96 \\
15. & DD & 100 & 100 & 90 & 97 \\
16. & UZA & 57 & 75 & 50 & 61 \\
17. & YM & 100 & 100 & 95 & 98 \\
18. & GNW & 96 & 90 & 90 & 92 \\
19. & AHP & 85 & 70 & 82 & 79 \\
20 & MHP & 76 & 80 & 80 & 79 \\
. & \multicolumn{7}{c}{ Total } \\
\hline \multicolumn{7}{c}{ Rata-rata Nilai } \\
\hline
\end{tabular}

Dilihat dari nilai siswa, maka individu yang memperoleh skor $\geq 66,67$ ke atas masuk dalam kategori tinggi, skor 33,33 s.d 66,67 masuk kategori sedang, dan siswa yang memperoleh skor $\leq 33,33$ masuk dalam kategori rendah. Berikut penjabarannya melalui tabel di bawah ini.

TABEL 4.

KATEGORI KEMAMPUAN MENULIS KARANGAN NARASI MENGGUNAKAN METODE SHOW NOT TELL PADA SISWA KELAS V MI NAHDLATUL MUJAHIDIN JEMPONG

\begin{tabular}{|c|c|c|c|c|c|}
\hline \multirow{2}{*}{ No } & \multirow{2}{*}{$\begin{array}{l}\text { Nama } \\
\text { Siswa }\end{array}$} & \multirow{2}{*}{ Nilai } & \multicolumn{3}{|c|}{ Kategori } \\
\hline & & & Tinggi & Sedang & Rendah \\
\hline 1. & MRAR & 95 & $\sqrt{ }$ & & \\
\hline 2. & ML & 67 & $\sqrt{ }$ & & \\
\hline 3. & MA & 87 & $\sqrt{ }$ & & \\
\hline 4. & RAU & 47 & & $\sqrt{ }$ & \\
\hline 5. & HLM & 50 & & $\sqrt{ }$ & \\
\hline 6. & PMA & 86 & $\sqrt{ }$ & & \\
\hline 7. & MJ & 98 & $\sqrt{ }$ & & \\
\hline 8. & HYM & 91 & $\sqrt{ }$ & & \\
\hline 9. & SDS & 81 & $\sqrt{ }$ & & \\
\hline 10. & $\mathrm{NH}$ & 94 & $\sqrt{ }$ & & \\
\hline 11. & ATF & 91 & $\sqrt{ }$ & & \\
\hline 12. & ARHD & 89 & $\sqrt{ }$ & & \\
\hline 13. & EAR & 92 & $\sqrt{ }$ & & \\
\hline 14. & $\mathrm{AR}$ & 96 & $\sqrt{ }$ & & \\
\hline 15 . & DD & 97 & $\sqrt{ }$ & & \\
\hline 16. & UZA & 61 & & $\sqrt{ }$ & \\
\hline 17. & YM & 98 & $\sqrt{ }$ & & \\
\hline 18. & GNW & 92 & $\sqrt{ }$ & & \\
\hline 19. & AHP & 79 & $\sqrt{ }$ & & \\
\hline 20. & MHP & 79 & $\sqrt{ }$ & & \\
\hline \multicolumn{2}{|c|}{ Jumlah } & 1670 & 17 & 3 & \\
\hline \multicolumn{2}{|c|}{ Rata-Rata } & 83,5 & & & \\
\hline
\end{tabular}

1) Persentase masing-masing kategori

Untuk mendapatkan persentase masing-masing kategori tinggi, sedang, dan rendah dapat dihitung melalui rumus berikut.

$$
\mathrm{P}=\frac{f}{N} \times 100 \%
$$

Kategori tinggi $=\frac{17}{20} \times 100 \%=85 \%$

Kategori sedang $=\frac{3}{20} \times 100 \%=15 \%$

Kategori rendah $=\frac{0}{20} \times 100 \%=0 \%$

Berdasarkan hasil perhitungan tersebut, diketahui bahwa secara keseluruhan siswa yang mendapat kategori tinggi sebesar 85\%, kategori sedang $15 \%$, dan kategori rendah $0 \%$. Hasil ini menunjukkan tidak ada siswa yang berada pada kategori rendah.

2) Indeks Prestasi Kelompok
Adapun penghitungan indek prestasi kelompok dapat dihitung menggunakan rumus berikut.

$$
\begin{aligned}
\mathrm{IPK} & =\frac{\frac{M}{S M i}}{S M .5} \times 100 \\
\mathrm{IPK} & =\frac{85.50}{100} \times 100 \\
\mathrm{IPK} & =83.5
\end{aligned}
$$

Dengan demikian, penghitungan indeks prestasi kelompok sebesar 83.5 termasuk dalam kategori tinggi.

\section{Pembahasan}

Penelitian ini berlangsung di MI Nahdlatul Mujahidin pada kelas V semester I. Penelitian ini merupakan penelitian kuantitatif deskriptif. Penelitian ini bertujuan untuk mendeskripsikan kemampuan menulis karangan narasi menggunakan metode show not tell pada siswa kelas V MI Nahdlatul Mujahidin Jempong. Materi penelitian ini mencakup tentang kemampuan siswa menulis karangan narasi dengan menggunakan metode show not tell. Narasi merupakan suatu bentuk wacana yang sasaran utamanya adalah segala kejadian yang dijalin dan dirangkai menjadi sebuah peristiwa yang terjadi dalam satu kesatuan waktu, atau sebuah penggambaran tentang peristiwa yang sudah terjadi (Keraf, 2010: 136).

Digunakannya metode show not tell sebagai metode dalam penelitian ini dikarenakan bahwa metode ini tidak membatasi siswa mencurahkan imajinasi serta kreativitasnya ke dalam cerita pendek yang ditulis. Show not tell membebaskan imajinasi siswa, sehingga siswa dapat melakukan proses kreativitasnya secara penuh. Kelas V SD/MI merupakan fase perkembangan daya imajinasi. Siswa akan lebih mudah menuangkan tulisan yang ditulis berdasarkan pada pengalaman yang mereka miliki.

Pada pelaksanaan kegiatan menulis karangan narasi dengan menggunakan metode show not tell, siswa melakukannya dengan cara individu. Pemberian tugas secara individu dilakukan karena setiap siswa memiliki pengalaman dan daya imajinasi yang berbeda-beda.

Penerapan metode show not tell, dapat mendorong siswa untuk berpikir, berinisiatif, berkreasi, dan meningkatkan kreativitas sehingga dalam pembelajaran menulis cerpen siswa tidak merasa bosan dan hasil yang dicapai dapat meningkat (De Porter dan Hernacki (2009: 192). Pernyataan ini sejalan dengan hasil penelitian yang memperlihatkan kemampuan menulis karangan narasicukup tinggi. Melalui penerapan metode tersebut, terlihat bahwa siswa antusias dalam mengikuti proses pembelajaran. Hasil tersebut dapat dilihat melalui observasi yang telah dilakukan pada saat proses pembelajaran berlangsung.

Selain itu, nilai yang diperoleh siswa sebagian besar berada pada kategori tinggi. Adapun hasil kemampuan menulis karangan narasi siswa kelas V MI Nahdlatul Mujahidin NW Jempong menunjukkan bahwa terdapat 17 orang siswa (85\%) yang berada pada kategori skor tinggi dan 3 orang siswa (15\%) berada pada kategori sedang. Hasil ini menujukkan bahwa penerapan metode show not tell dapat berdampak pada kemampuan menulis karangan narasi siswa kelas V MI Nahdlatul Mujahidin NW Jempong, Ampenan. 


\section{KESIMPULAN DAN SARAN}

\section{Simpulan}

Berdasarkan hasil penelitian, diperoleh data bahwa kemampuan menulis karangan narasi menggunakan metode show not tell pada siswa kelas V MI Nahdlatul Mujahidin NW Jempong, Ampenan tergolong tinggi. Hal ini terjadi karena penggunaan metode show not tell yang dapat mempermudah pemahaman sisiwa dalam menulis karangan narasi. Adapun hasilnya dapat dijabarkan sebagai berikut. 1) Kemampuan individual, meliputi kategori tinggi sebanyak 17 orang siswa dan kategori sedang berjumlah 3 orang siswa. 2) Persentase masing-masing kategori, di antaranya kategori tinggi sebesar 85\%, kategori sedang sebesar $15 \%$, dan kategori rendah $0 \%$. 3) Indeks prestasi kelompok sebesar 85.5 sehingga termasuk dalam kategori IPK tinggi.

\section{Saran}

Berdasarkan hasil penelitian yang dilakukan, disarankan beberapa hal sebagai berikut.

a. Membuat rancangan pembelajaran yang kreatif dan menyenangkan dengan menerapkan beberapa metode atau strategi pembelajaran.

b. Memberikan apresiasi kepada siswa yang telah berhasil mencapai tujuan pembelajaran.

c. Memberikan kesempatan kepada siswa untuk mengembangkan imajinasi dan kreativitas melalui tulisan atau karangan.

d. Hasil penelitian ini dapat dikembangkan bagi peneliti lain, misalnya jenis penelitian eksperimen atau PTK.

\section{DAFTAR RUJUKAN}

[1] Arikunto, S. 2010. Prosedur Penelitian (Suatu Pendekatan Praktik). Jakarta: Rineka Cipta

[2] DePorter, Bobbi, dan Mike Hernacki. 2009. Quantum Learning: Membiasakan Belajar Nyaman dan Menyenangkan. Diterjemahkan oleh Alwiyah Abdurrahman. Bandung: Kaifa

[3] Djatmika, Primasita, F. A., \& Priyanto, A. D. (2011). Strategi meningkatkan kualitas olah bahasa untuk cerita pendek siswa sekolah dasar dengan pendekatan genrebased. Lingua, 6 (2), 115-125

[4] Keraf, Gorys. (2010). Argumentasi dan Narasi. Jakarta: Kompas Gramedia

[5] Nurgiyantoro, Burhan. (2001). Penilaian Pembelajaran Bahasa dan Sastra. Yogyakarta: BPFE Yogyakarta

[6] Sugiran. (2008). Peningkatan Keterampilan Menulis Narasi Dengan Memanfaatkan Pengalaman Menulis Buku Harian. Jurnal Kependidikan Interaksi, 3 (3), 53 